\title{
The Effects of Sustainability Orientation, Sustainability Education, and Risk Perception Towards Green Entrepreneurship Among Young Generations
}

\author{
Rudi Yacub ${ }^{1}$, Herlina Herlina ${ }^{2}$, Irfan Sophan Himawan ${ }^{3}$ \\ ${ }^{1}$ Universitas Putra Indonesia, West Java, Indonesia \\ ${ }^{2}$ Universitas Mandiri, West Java, Indonesia \\ ${ }^{3}$ Politeknik Tri Mitra Karya Mandiri, West Java, Indonesia \\ *Corresponding author.Email: lina.andiirawan@gmail.com
}

\begin{abstract}
This study aimed to identify green entrepreneurship among the younger generations, especially the students, with their activities in helping improve the economy while still trying to preserve the surrounding environment. This study used a deductive approach that collects data in a cross-sectional manner with quantitative data processing using a Structural Equation Model (SEM) to analyze the data from 412 respondents in 11 stateuniversities in Indonesia through questionnaire distributions. The result of this study is that there is a positive and significant effect of sustainability orientation and sustainability education on green entrepreneurship. In contrast, risk perception is not significant towards green entrepreneurship. Current research is limited to the prospective young entrepreneurs, especially among the college students. The importance of this research is to provide awareness to inspire young entrepreneurs to carry out environmental-based economic activities and the results of this research can also be used as a reference for studying in universities around the world in any discipline. It will also support the governments, policymakers, and university authorities to develop the tailoredawareness programs through curriculum development towards green and sustainable entrepreneurship. The creation of good and healthy environmental conditions can provide a better place to live for future generations around the world.
\end{abstract}

Keywords: Green entrepreneurship, sustainability orientation, sustainability education, risk perception, future generation

\section{INTRODUCTION}

The green economy that has been called so by the United Nations Agency, namely UNICEF, has caused a pretty good impact on many countries around the world, especially the developing countries. This is because the natural environment in developing countries is not yet comfortable and clean from all kinds of pollution. So, the hope of preserving the world's natural environment is now directed towards preserving the survival of future generations regarding a proper and healthy place to live in [1]. These objectives can be directed towards a green economy based on social and green economic reasons, which are meant to be engaged in the economic sector while maintaining the environmental sustainability. The indications point to a green economy that have both social and economic reasons [2]. The network was previously aimed at community recovery or welfare, but the current business model is more responsible for the environment, thus this reflects the sustainability [3].

In developing countries, the support for a varied and healthy ecosystem shows that a green economy perspective is carried-out by collaborating social, political, and cultural factors [4]. So, the current era of the younger generations is expected to be able to become sustainably-competent entrepreneurs [2]. The young generations should have been directed at an early age towards a sustainable future business [5].

Based on the above objectives, in order to improve the economy in Indonesia and maintain the environmental sustainability, education and entrepreneurial attitude will be further enhanced and raised for the younger generations and it is hoped that more young entrepreneurs will be able to explore green entrepreneurship. Therefore, this study aimed to investigate the tendency of the younger generations, in this case the students in Indonesia, towards green entrepreneurship. This research also refers to a sustainable catalytic economic function [6] in order to accelerate the pace of the green economy in Indonesia.

\section{LITERATURE REVIEW AND CONCEPTUAL FRAMEWORK}

Meeting the needs of future generations is necessary for a sustainable development that aims to raise their interests or needs and address social problems [7] [8]. The concept of 
sustainable development itself has developed into certain fields of research such as entrepreneurship. However, green entrepreneurship is still maintained as a form of comprehensive environmental protection for sustainable business activities [9]. Business as a whole is thought to be affected by natural environmental problems [10] [11].

Furthermore, in order to overcome the environmental problems, special and serious attentions must be paid to the problems of survival and welfare in any entrepreneurial activities [12]. A valuable business according to Schaper is a business that generates a business basis in green perception for the formation and growth of environmental sustainability [13]. At the company level, a green economy is developed through CSR as a form of company's concern on the surrounding community which covers the company's internal and external practices, namely their environment [14].

\subsection{Green Entrepreneurship}

The study of green entrepreneurship also found several other factors that underlie the formation of a sustainable business, namely social and political factors that are thought to influence environmental decision making and sustainability in a country. Hence, the result is a closer relationship between socio-economic and socio-political factors in a country and the environment [15]. Recent studies investigated sustainable motivational behavior which consists of three aspects, namely individual awareness and self-reliance on trust in health services and environmental benefits, and the sustainability of other people's norms [16] [17].

Other research stated that the sustainability factor is related to the intention of small businesses to exploit open sustainability described as meeting the sustainability challenges through the exploitation of internal and external initiatives, obtained from empirical data, which was collected from 139 companies [18].

In Indonesia, there are many studies that examine entrepreneurship in general, but not many have been specific, for example green entrepreneurship or social entrepreneurship, and so on. However, researchers mostly ignore that the involvement with green business is closely related to green entrepreneurship [19]. Today's younger generations are more interested in running their own business [20]. Given the gaps in existing literature on green entrepreneurship, a conceptual model was developed (Figure 1) in order to investigate the trend towards green entrepreneurship among Indonesia's young generations through sustainability orientation, educational orientation, academic skills, and social skills.

\subsection{Sustainability Orientation}

The idea of a sustainability orientation is raised through the mastery of insights on entrepreneurship [21]. Furthermore,
Kuckertz and Wagner argued that sustainability orientation positively and significantly affects the entrepreneurial intentions among the students. In addition, sustainability orientation is considered as an inspiring and emotional constituent in the entrepreneurial context [22]. So, in this case, the researcher suggests that universities in Indonesia should emphasize more on sustainable entrepreneurship education in order to preserve the environment.

\subsection{Sustainability Education}

Researchers in this field have expressed their confidence that continual education will inspire a paradigm transfer in teaching, thinking, and learning for a sustainable world [23]. In the context of student affairs, higher education has a significant impact on entrepreneurial skills and attitudes [24]. Therefore, sustainability education is seen as a valid and reliable way in which the growth in activities and a more sustainable lifestyle can ultimately be achieved [25].

\subsection{Risk Perception}

Entrepreneurs always think about the risks as the case with green entrepreneurial entrepreneurs. In theory, it is also mentioned that entrepreneurs have a greater risk tendency than others [26]. Thus, it can be said that in carrying out a business activity plan, risky actions are always consciously thought of. However, later empirical research showed that risk trends are not associated with business formation [27]. So, even green entrepreneurship does not always show a risk tendency. Another finding is that not all entrepreneurs always think of a higher risk tendency to dare to start their business. There are those who think less about the risk, so they immediately start their business without thinking about the risk initially. In addition, there are also those arguing that individuals want to start a business because they think that understanding the entrepreneurial work has less risk than do non-entrepreneurs [28].

In short, the literature above has recognized that sustainability orientation, sustainability education, risktaking, and inspiration become the most suitable predictors of entrepreneurship. In contrast, in Indonesian context, for the first time this type of study is conceptualized by linking these factors to green entrepreneurial trends. Thus, the researcher proposed the following hypothesis and Figure 1 for further investigation as follows:

$\mathrm{H}_{1}$ : Sustainability orientation has a positive and significant effect on green entrepreneurship.

$\mathrm{H}_{2}$ : Sustainability education has a positive and significant effect on green entrepreneurship.

$\mathrm{H}_{3}$ : Risk perception has a positive and significant effect on green entrepreneurship. 


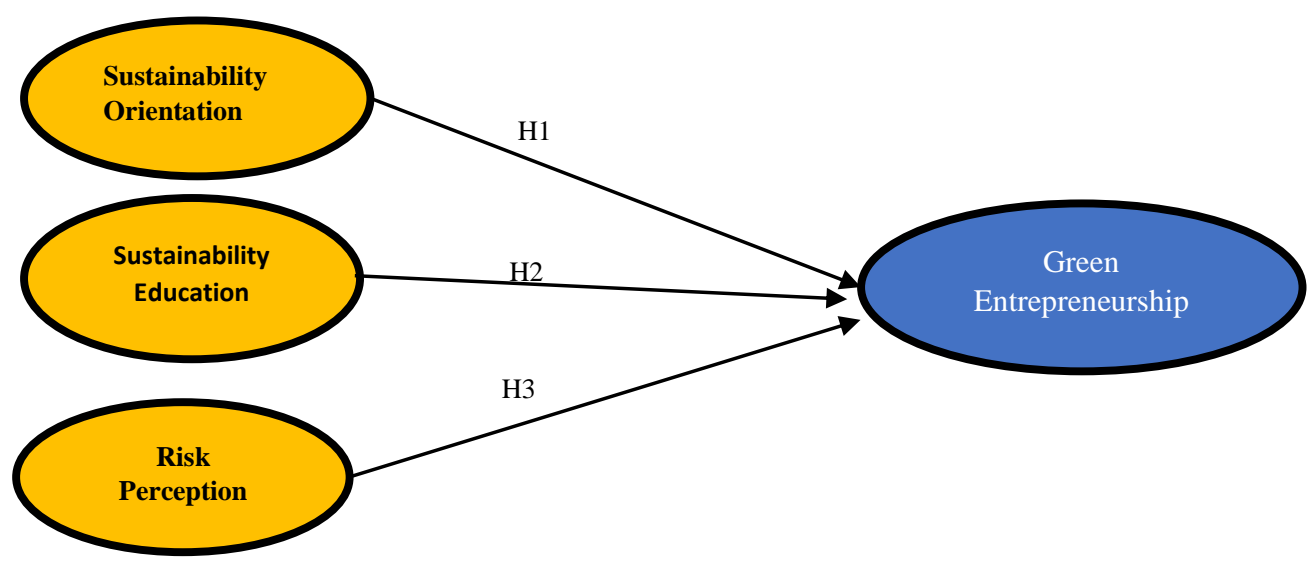

Figure 1 The Conceptual Model

\section{RESEARCH METHODS}

\subsection{Respondents and Survey Tool}

This research used a deductive approach involving 412 undergraduate students who have taken entrepreneurship education. The students' average age ranged from 18 to 23 years. As a survey tool, we used the questionnaire that had been prepared in advance with the design of the research instrument. It is expected that these social tools can be widely and critically accepted by the students [29] and reinforced [30]. The questionnaire was adopted from the green entrepreneurship literature.

\subsection{Sampling Procedure and Sample Size}

The data was obtained from communicational activities with the teachers working in state-owned universities in Indonesia. The sampling technique was carried out randomly on the same occasion so as not to cause the sample bias. The questionnaire technique used the Google Form which is designed through Google Drive. This activity was done, because the universities are far apart. Furthermore, from the results of the questionnaire distribution, the researchers guarantee that the data is confidential, accurate, and anonymous. The data was recorded accurately, because it went directly from the students to the researcher's Google Drive database. Initially, we distributed 35 statements to some students in the city. Furthermore, we obtained 31 valid statement-items which were then used as a questionnaire distributed to all respondents amounting to 412 students that could be used for hypothesis testing purpose.

\subsection{Measurements}

\subsubsection{Sustainability Orientation}

This variable consists of 6 indicators and all of them are measured on a 5-point Likert scale, ranging from '1' (strongly disagree) to '5' (strongly agree).

\subsubsection{Sustainability Education}

This variable consists of 6 indicators and all of them are measured using a 5-point Likert scale, ranging from '1' (strongly disagree) to '5' (strongly agree).

\subsubsection{Risk Perception}

This variable consists of 5 indicators and all of them are measured using a 5-point Likert scale, ranging from ' 1 ' (strongly disagree) to '5' (strongly agree).

\subsubsection{Green Entrepreneurship}

This variable consists of 5 indicators and all of them are measured on a 5-point Likert scale, ranging from '1' (strongly disagree) to '5' (strongly agree).

\subsection{Data Analysis Technique}

This study used a cross-sectional data collection technique. The type of tool used is a survey lift which was distributed to analyze the answers of 412 students from 11 state-owned universities in Indonesia who have received entrepreneurial courses. Structural Equation Modeling (SEM) was used in this study for data analysis purpose.

\section{RESULTS AND DISCUSSIONS}

\subsection{Respondents' Demography}

The demographic profile of respondents has benefits in understanding the social and economic problems as well as being able to identify the potential solutions [31]. Based on the data obtained, 136 respondents are male (33\%) and 276 respondents are female $(67 \%)$. We describe the age of the respondents as follows: $400(97.30 \%)$ of respondents aged between 19 and 22 years and $12(2.70 \%)$ of respondents aged between 23 years and 25 years. With regard to their level of study year, 122 respondents $(29.62 \%)$ were Seniors, $134(32.52 \%)$ were Juniors, and $156(37.86 \%)$ respondents 
were Sophomores. We didn't distribute the questionnaires to Freshmen. (Table 1).

Table 1 The Demography of Respondents

\begin{tabular}{cccc}
\hline Classification & Category & Frequency & Percentage \\
\hline Gender & Male & 136 & 33 \\
\hline & Female & 276 & 67 \\
\hline Age & Total & 412 & 100 \\
\hline & $19-22$ & 400 & 97.30 \\
\hline Year of Study & $23-25$ & 12 & 2.70 \\
\hline & Total & 412 & 100 \\
\hline & Sophomore & 156 & 37.86 \\
\hline & Junior & 134 & 32.52 \\
\hline & Senior & 122 & 100 \\
\hline
\end{tabular}

Source: Data Analysis by Authors

\subsection{Descriptive Statistics, Reliability Assessment, and Pearson's Correlation}

The observation of respondents' participation used the descriptive statistics. The highest mean occurred in sustainability education variable $(1,642)$ and sustainability orientation variable $(1,655)$, while the lowest mean occurred in risk perception variable (904). Meanwhile, the mean for green entrepreneurship variable was 1,533 . The criteria for the classification of research variables are displayed as follows (Table 2).

Table 2 Criteria of Research Variable Classification

\begin{tabular}{clccccc}
\hline \multirow{2}{*}{ No. } & Variable & \multicolumn{4}{c}{ Classification Range } \\
\cline { 3 - 7 } & & $\begin{array}{c}\text { Very Low } \\
\mathbf{4 1 2 - 6 5 8}\end{array}$ & $\begin{array}{c}\text { Low } \\
\mathbf{6 5 9 - 9 0 5}\end{array}$ & $\begin{array}{c}\text { Enough } \\
\mathbf{9 0 6 - 1 1 5 2}\end{array}$ & $\begin{array}{c}\text { High } \\
\mathbf{1 1 5 3 - 1 3 9 9}\end{array}$ & $\begin{array}{c}\text { Very High } \\
\mathbf{1 4 0 0 - 1 6 4 7}\end{array}$ \\
\hline 1. & Sustainability Orientation & - & - & - & - & 1,655 \\
\hline 2. & Sustainability Education & - & - & - & - & 1,642 \\
\hline 3. & Risk Perception & - & 904 & - & - & - \\
\hline 4. & Green Entrepreneurship & - & - & - & - & 1,533 \\
\hline
\end{tabular}

Source: Data Analysis by Authors

Likewise, the highest upper-range for standard deviation occurred in risk perception variable (1.957), while the lowest occurred in green entrepreneurship variable (1.126). The values of 1.177 and 1.131 were observed for the sustainability orientation and sustainability education variables. Furthermore, higher consistency was noted among the items for green entrepreneurship variable (0.877), compared to the other variables (sustainability orientation $=0.811$, sustainability education $=0.797$, and risk perception $=0.513$ ). Finally, we detected the acceptable Pearson's correlations ranging between 0.100 and 0.477 (Table 3).

Table 3 Descriptive Statistics, Reliability, and Correlation

\begin{tabular}{clccccccc}
\hline No. & \multicolumn{1}{c}{ Variable } & Mean & $\begin{array}{c}\text { Standard } \\
\text { Deviation }\end{array}$ & $\begin{array}{c}\text { Alpha } \\
(\boldsymbol{\alpha})\end{array}$ & $\mathbf{1}$ & $\mathbf{2}$ & $\mathbf{3}$ & $\mathbf{4}$ \\
\hline 1. & Green Entrepreneurship & 1,533 & 1.126 & 0.877 & $\mathbf{1}$ & & & \\
\hline 2. & Sustainability Orientation & 1,655 & 1.177 & 0.811 & $0.402^{* *}$ & $\mathbf{1}$ & & \\
\hline 3. & Sustainability Education & 1,642 & 1.131 & 0.797 & $0.279^{* *}$ & $0.477^{* *}$ & $\mathbf{1}$ & \\
\hline 4. & Risk Perception & 904 & 1.957 & 0.513 & $0.100^{*}$ & $0.213^{* *}$ & $0.320^{* *}$ & $\mathbf{1}$ \\
\hline **ignificant at the 0.01 level (2-tailed) & & & & & & &
\end{tabular}

*Significant at th

Source: Data Processed by Authors

\subsection{The Fitness Model and Hypothesis Testing}

The model-fit statistics (absolute and incremental indices) are the parameters used to measure the strength of this statistical test [32]. Regarding the Absolute Conformity
Index, the chi-squared value highlights the insignificant value of CMIN /df (2.875; p > 0.005) which confirms the positive sign of model fit with the data [33]. Likewise, the values for the GoF Index (GFI = 0.971), the adjusted Goodness of the Suitability Index (AGFI $=0.947)$, and the 
Root Mean Square Error of Approximation (RMSEA = 0.037 ) lie within the acceptable ranges. Subsequently, the values of the Incremental-Fit Index, including the Normed-
Fit Index $(\mathrm{NFI}=0.957)$ and the Comparative-Fit Index $(\mathrm{CFI}$ $=0.967)$, are revealed to be acceptable. These scores meet the absolute criteria of the fit-model [33] (Table 4).

Table 4 Goodness-of-Fit Statistics

\begin{tabular}{ccccccc} 
Model Fit & CMIN/df & GFI & AGFI & NFI & CFI & RMSEA \\
\cline { 2 - 6 } Indicators & 2.875 & 0.971 & 0.947 & 0.957 & 0.967 & 0.037 \\
\hline $\begin{array}{c}\text { Suggested } \\
\text { values }\end{array}$ & $<3$ & $>0.90$ & $>0.90$ & $>0.90$ & $>0.90$ & $<0.05$ \\
Salues & & & & & &
\end{tabular}

Source: Data Processed by Authors

Furthermore, to explain the relationship between several variables used Structural Equation Modeling (SEM). This technique allows researchers to examine the relationship between several dependent and independent variables in an instant [33]. We processed the proposed relationship data based on Standard Error (SE), Critical Ratio (CR), and significance level $(*=p<0.05)$. The result shows a positive and significant relationship between Sustainability Orientation and Green Entrepreneurship ( $\mathrm{SE}=0.069$; $\mathrm{CR}=$
6.658; $\mathrm{p}<0.05)$. Therefore, $\mathrm{H}_{1}$ was supported. Likewise, the SEM weights for $\mathrm{H}_{2}(\mathrm{SE}=0.079 ; \mathrm{CR}=6.413$; $\mathrm{p}<0.05)$ states a positive and significant relationship between sustainability education and green entrepreneurship. Thus, $\mathrm{H}_{2}$ was accepted. Finally, the relationship between Risk Perception and Green Entrepreneurship $\left(\mathrm{H}_{3}\right)$ was not significant $(\mathrm{SE}=0.043 ; \mathrm{CR}=0.574 ; \mathrm{p}>0.05$ ) (Table 5 and Figure 2). In general, $\mathrm{H}_{1}$ and $\mathrm{H}_{2}$ were accepted, while $\mathrm{H}_{3}$ was not.

\section{Table 5 Hypothesis-Testing Results}

\begin{tabular}{llllllll}
\hline No. & Independent variable & Dependent variable & Estimate & SE & CR & $p$ & Decision \\
\hline 1. & $\begin{array}{l}\text { Sustainability } \\
\text { Orientation }\end{array}$ & $\begin{array}{l}\text { Green } \\
\text { Entrepreneurship }\end{array}$ & 0.577 & 0.069 & 6.658 & $*$ & Accepted \\
\hline 2. & $\begin{array}{l}\text { Sustainability } \\
\text { Education }\end{array}$ & $\begin{array}{l}\text { Green } \\
\text { Entrepreneurship }\end{array}$ & 0.498 & 0.079 & 6.413 & $*$ & Accepted \\
\hline 3. & Risk Perception & $\begin{array}{l}\text { Green } \\
\text { Entrepreneurship }\end{array}$ & 0.053 & 0.043 & 0.574 & $>0.05$ & $\begin{array}{c}\text { Not } \\
\text { Accepted }\end{array}$ \\
\hline
\end{tabular}

\section{Source: Data Processed by Authors}

Furthermore, this study proposed three hypotheses based on the conceptual model, while the results of data processing indicate that there is a positive and significant effect of sustainability orientation on green entrepreneurship. Then $\mathrm{H}_{1}$ was accepted. This is in line with the research conducted by [21] and [34]. Furthermore, this positive and significant result is also acquired in the effect of sustainability orientation on green entrepreneurial goals in the student environment [22].

However, our results contradict [35] who 2 years ago revealed a negative effect of sustainability orientation on entrepreneurial action, even though individuals having entrepreneurial activities are considered to be reliable in the changing society. The results of [35] suggest that new products creation can guarantee the value to consumers, while businesses take unavoidable risks.

Next, regarding $\mathrm{H}_{3}$, there is no significant effect of risk perception on green entrepreneurship. Thus, $\mathrm{H}_{3}$ was not accepted. This result is supported by [35] concluding that individuals may be less inclined to pursue decisions related to perceived risk due to greater likelihood of loss and uncertainty. So, in this case, students do not think too much about risk. The reason underlying this phenomenon is because there are not many students in Indonesia who run business, one of which is because they still focus on achieving learning outcomes. Hence, opening a new business while studying is considered as a side job. 


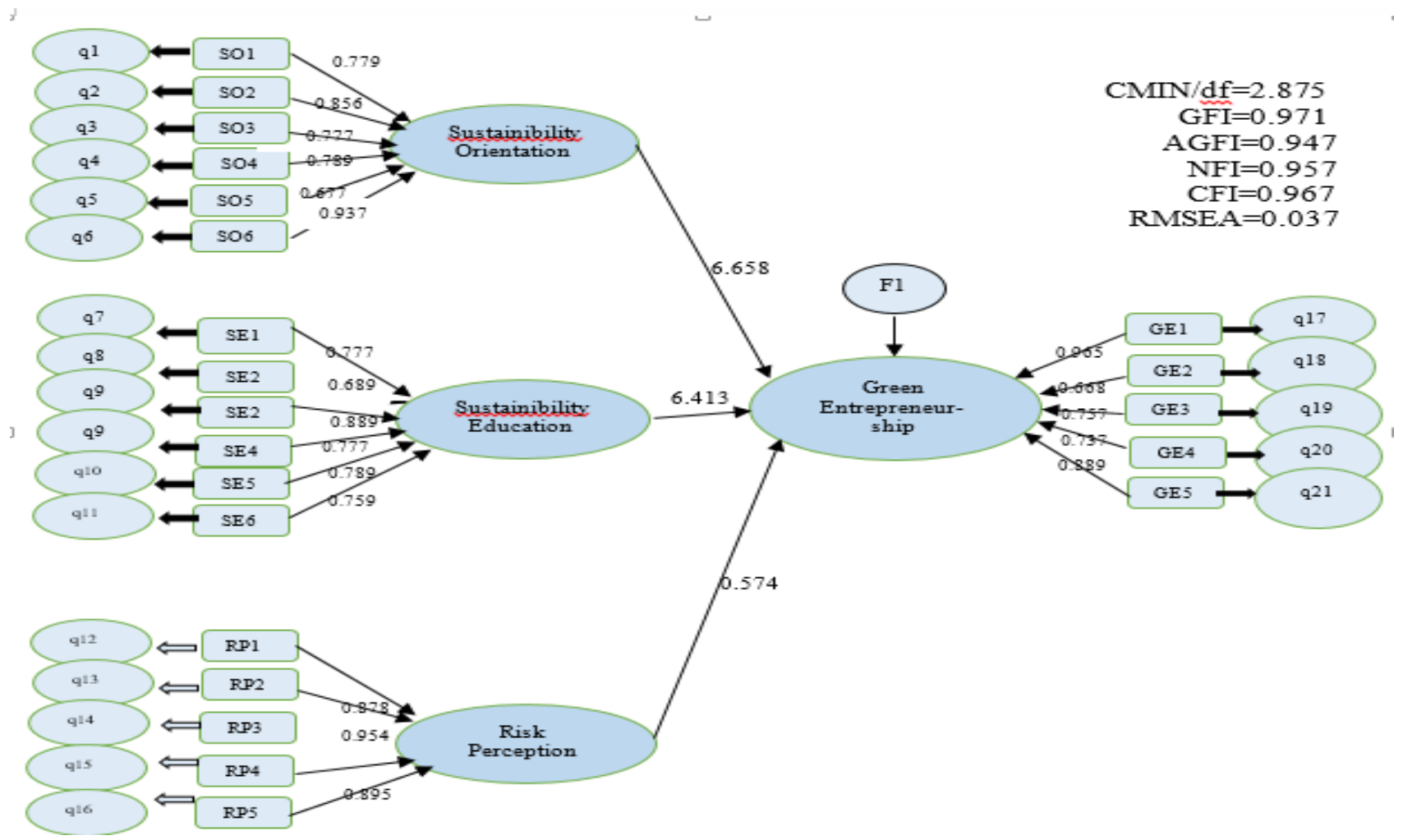

Figure 2 Structural Equation Model

\section{LIMITATION OF THIS STUDY}

The conduct of this study is limited to the number of variables as a driving factor for green entrepreneurship. Thus, hopefully the future studies can examine several more factors which are as specific as the risk perception applied in this study.

\section{CONCLUSIONS}

In conclusion, this study revealed the positive and significant effects of sustainability orientation and sustainability education on green entrepreneurship goals among the youths in Indonesia. On contrary, risk perception was not proven to be positive and significant in predicting green entrepreneurship. This is possible to happen, because in the beginning of green entrepreneurship formation, risk perception is not really needed. Students prioritize their courage first to try doing green entrepreneurship rather than thinking more about the risks they will face. The findings of this study are also proven to confirm the green economic development which must be initiated with a green business movement from the low level.

Meanwhile, the supporting factors towards green entrepreneurship, such as the sustainability orientation and sustainability education, should be given to potential young entrepreneurs in Indonesia. Furthermore, the importance of this research is to provide the awareness to aspire young entrepreneurs to carry out the environmental-based economic activities and the results of this research can also be used as a reference for learning by universities around the world in any discipline. In addition, these results are also expected to be a source of inspiration and emotional consistency for students in growing their green entrepreneurial business, which in turn will improve the green economy as a whole. We also recommend that future research is expected to be continued and developed in other national contexts such as other economic fields in the education sector.

\section{ACKNOWLEDGMENT}

All costs for the publication of this article are borne by the Authors.

\section{CONFLICTS OF INTEREST}

The authors declare no conflict of interest.

ORCID: https://orcid.org/0000-0002-1363-4761

\section{REFERENCES}

[1] UNESCO. (2012). Shaping the Education of Tomorrow 2012 Report on the UN Decade of Education for Sustainable Development, Abridged DESD Monitoring and Evaluation.

[2] Richomme-Huet, K., \& De Freyman, J. (2014). What sustainable entrepreneurship looks like: An 
exploratory study from a student perspective. Social Entrepreneurship: International Studies in

Entrepreneurship, 29, 155-177.

[3] Rahman, S. A., Amran, A., Ahmad, N. H., \& Taghizadeh, S. K. (2016). Enhancing the Wellbeing of Base of the Pyramid Entrepreneurs through Business Success: The Role of Private Organizations. Social Indicators Research, 127(1), 195-216. https://Doi.Org/10.1007/S11205-015-0951-4

[4] Shaheed, H. A. (2020). Causal Relationship Model of Sustainable Consumption Behavior of Education Ecology, Environment and Conservation. (February).

[5] Maziriri, E. T., Mapuranga, M., Maramura, T. C., \& Nzewi, O. I. (2019). Navigating on The Key Drivers for A Transition to A Green Economy: Evidence from Women Entrepreneurs in South Africa.

Entrepreneurship And Sustainability Issues, 7(2), 1686-1703. https://Doi.Org/10.9770/Jesi.2019.7.2(62)

[6] Parrish, B. D., \& Foxon, T. J. (2006). Sustainability Entrepreneurship And Equitable Transitions To A LowCarbon Economy. Greener Management International, (55), 47-62. https://Doi.Org/10.9774/Gleaf.3062.2006 .Au.00006

[7] Brundtland, G. (1987). Report of The World Commission on Environment And Development: Our Common Future. United Nations General Assembly Document A/42/427

[8] Siegmund-Schultze, N. (2013). Signalwege Als Zielstrukturen. Deutsches Arzteblatt International, 110(25), 1546-1558.

[9] Ndubisi, N. O., \& Nair, S. R. (2009). Green Entrepreneurship (GE) and Green Value Added (GVA): A Conceptual Framework. International Journal of Entrepreneurship, 13(Special Issue), 21-34.

[10] Coddington, W. (1993). Environmental Marketing's New Relationship with Corporate Environmental Management. Environmental Quality Management, 2, 297-302. http://dx.doi.org/10.1002/ tqem.3310020310

[11] Banerjee, S., Gulas, C. S., \& Iyer, E. (2013). Shades of Green : A Multidimensional Analysis of Environmental Advertising. (May 2015), 37-41. https://Doi.Org/10.1080/00913367.1995.10673473

[12] Baker, W. E., \& Sinkula, J. M. (2005). Environmental Marketing Strategy and Firm Performance : Effects on New Product Performance and
Market Share. 33(4), 461-475. https://Doi.Org/10.1177/0092070305276119

[13] Santini, C. (2017). Ecopreneurship and Ecopreneurs : Limits, Trends, and Characteristics. (2010). https://Doi.Org/10.3390/Su9040492

[14] Shah, K. U., Arjoon, S., \& Rambocas, M. (2016). Aligning Corporate Social Responsibility with Green Economy Development Pathways in Developing Countries. https://Doi.Org/10.1002/Sd.1625

[15] Mukherjee, S. (2014). Do Non-Economic Factors Influence Environmental Performance Of A Country? Recent Empirical Evidence. (June).

[16] Chen, S. Y. (2018). True Sustainable Development of Green Technology: The Influencers and Risked Moderation of Sustainable Motivational Behavior. (May), 1-15. https://Doi.Org/10.1002/ Sd.1863

[17] Gibbs, D., \& Neill, K. O. (N.D.). Green Entrepreneurship : Building A Green Economy? Evidence From The UK. In Contemporary Issues In Entrepreneurship Research (Vol. 2). https://Doi.Org/10.1108/S2040-7246(2012) 0000002008

[18] Ukko, J., \& Saunila, M. (2019). Sustainable Development: Implications and Definition for Open Sustainability. (June 2018), 321-336. https://Doi.Org/10.1002/Sd.1904

[19] Ferguson, D. (N.D.). Enabling Factors of Green Entrepreneurship : A Case Study of Organic Agriculture Produce in The Sindh and Balochistan Provinces Of. 181-190.

[20] Shah, K. U., Arjoon, S., \& Rambocas, M. (2016). Aligning Corporate Social Responsibility With Green Economy Development Pathways in Developing Countries. https://Doi.Org/10.1002/Sd.1625

[21] Dean, T. J., \& Mcmullen, J. S. (2007). Toward A Theory of Sustainable Entrepreneurship: Reducing Environmental Degradation through Entrepreneurial Action. Journal of Business Venturing, 22(1), 50-76. https://Doi.Org/10.1016/J.Jbusvent.2005.09.003

[22] Kuckertz, A., \& Wagner, M. (2010). The Influence of Sustainability Orientation on Entrepreneurial Intentions - Investigating The Role of Business Experience. Journal of Business Venturing, 25(5), 524 539. https://Doi.Org/10.1016/J.Jbusvent. 2009.09.000 
[23] Unesco. (2012). Shaping The Education of Tomorrow. Report on the Undecade of Education for Sustainable Development, Abridged DESD Monitoring And Evaluation.

[24] Tognazzo, A., Gianecchini, M., \& Gubitta, P. (2017). Educational Context and Entrepreneurial Intentions of University Students: An Italian Study. Contemporary Issues In Entrepreneurship Research, 7, 47-74. https://Doi.Org/10.1108/S2040-

724620170000007008

[25] Sterling, S. (2010). Learning For Resilience, or The Resilient Learner? Towards A Necessary

Reconciliation in A Paradigm of Sustainable Education. Environmental Education Research, 16(5-6), 511-528. https://Doi.Org/10.1080/13504622. 2010.505427

[26] Brockhaus Sr., R. H. (1980). Risk Taking Propensity of Entrepreneurs. Academy of Management Journal, 23(3), 509-520.

[27] Busenitz, L. W., \& Barney, J. B. (1997).

Differences between entrepreneurs and managers in large organizations: Biases and heuristics in strategic decision-making. Journal of Business Venturing, 12(1), 9-30. https://doi.org/10.1016/S0883-9026(96)00003-1

[28] Palich, L. E., \& Bagby, D. (1995). Using cognitive theory to explain rist taking. Elsevier, 9026(95), 425438.

[29] Rossi, P. H., Wright, J. D., \& Anderson, A. B. (1983). Sample Surveys: History, Current Practice, and Future Prospects (Eds.), Handbook of Survey Research. London: Academic Press.

[30] Dong, Y. (2013). Contingent Valuation of Yangtze Finless Porpoises in Poyang Lake, China. https://Doi.Org/10.1007/978-94-007-2765-6

[31] Gbadamosi, B. O. (2013). Demographic Information Sources and Utilization as Determinants of Educational Policy Making in South Western Nigeria. Educational Research Review, 8(21), 2049-2058.

[32] Setyawan, A. (2016). Apakah Gender Bermakna pada Model Pembentukan Minat. Manajemen Teori Dan Terapan, 2(2), 120-127.

[33] Hair, J., Black, W., Babin, B., Anderson, R., \& Tatham, R. (2006). Multivariate Data Analysis (6th Ed.). Upper Saddle River, Nj: Pearson Prentice Hall, Pearson Education, Inc.

[34] Soomro, B. A., Ghumro, I. A., \& Shah, N. (2020). Green entrepreneurship inclination among the younger generation: An avenue towards a green economy. Sustainable Development, 28(4), 585-594.

https://doi.org/10.1002/sd.2010

[35] Forlani, D., \& Mullins, J. W. (2000). Perceived risks and choices in entrepreneurs' new venture decisions. Journal of Business Venturing, 15(4), 305322. https://doi.org/10.1016/S0883-9026(98)00017-2. 